\title{
Strengthening the Role of Cadres and Village Midwives to Support the Cervical Cancer Awareness Movement in Puhu Payangan Village, Gianyar, Bali, Indonesia \\ Desak Putu Oki Lestari ${ }^{1 *}$, Sri Ratna Dewi ${ }^{2}$, Ni Wayan Armerinayanti ${ }^{1}$
}

\author{
${ }^{1}$ Department of Anatomical Pathology, Medical Education Study Program, Faculty of Medicine and Health \\ Education, Universitas Warmadewa, Bali, Indonesia \\ 2Department of Clinical Pathology, Medical Education Study Program, Faculty of Medicine and Health \\ Education, Universitas Warmadewa, Bali, Indonesia
}

Submitted: February 05 2019 ; Revised: February 10 ${ }^{\text {th }} 2021$; Accepted: March $02^{\text {nd }} 2021$

Keywords:
Cervical cancer
PAP smear
screening
Midwives
Health Cadres
Indonesia

Abstract Cervical cancer is the most common type of cancer in Balinese women, and most of the cervical cancer patients came in advanced condition. The health survey conducted in the village of Puhu, Payangan, Gianyar, found that the coverage of cervical cancer screening is $12 \%$, which is considered as low. Payangan's sub-district health centers (Puskesmas) have made an effort to give free PAP smear screenings to the local community, but it still has not received a good response. This is related to the community's lack of knowledge on cervical cancer, low awareness of cancer screening, and false stigma about PAP smear examination. To overcome this problem, an effort is needed to increase awareness about the need for PAP smear screening by shaping it into a cervix cancer awareness movement "Gardavi", involving village midwives and housewife members of Empowerment and Family Welfare Group (PKK) in Puhu Village as cadres. Methods that are used in this community service include training for midwives, activation of tiered information system involving midwives-cadres and the community, knowledge provision as well as motivating cadres. This event is done to increase the role of village midwives and cadres to actively participate in PAP smear screenings in their region, therefore, it may increase screening outcomes and lower mother morbidity and mortality numbers due to cervical cancer. This event results in increased midwives' knowledge and skill on the technique of sampling PAP smear independently, increased visits to the Community Health Sub-Center (Pustu) for PAP smear examination, creation of a midwives-cadres-community coordination system, cadres independently playing an active role in motivating the village community to do screening, as well as increased cadres' optimism.

\section{INTRODUCTION}

Up to the present, cervical cancer is still a health problem for women in Indonesia, specifically in Bali (Medik, 2011). There are a number of risk factors associated with cervical cancer, including not having regular PAP smears screening, having a history of sexually transmitted diseases, having sex with more than one sexual partner, having sex from a young age, smoking, and giving birth to a large number of children (Akinlotan \& Bolin, 2017). Most cervical cancer

ISSN 2460-9447 (print), ISSN 2541-5883 (online)

*Corresponding author: Desak Putu Oki Lestari

Faculty of Medicine and Health Science, Universitas Warmadewa, Jl. Terompong No.24, Sumerta Kelod, Kec. Denpasar Timur, Kota Denpasar, Bali 80239, Indonesia

Email: desakputuokilestari@gmail.com 
patients do not show symptoms and the symptoms usually appear at the advanced stage. The course of the disease from precancerous lesions to invasive cancer takes years to develop (Stoler, 2014). Knowing as soon as possible about the condition of the disease will certainly provide a better prognosis (Anfinan \& Sait, 2020). Cytological examination of the PAP smear screening is an examination that can be used to detect the presence of abnormal cervical epithelial cells (Catrino, 2015).

The cervical cancer screening program through the PAP smear examination has been proclaimed by the government as an early detection program implemented at the sub-district health centers (Puskesmas) (Republic of Indonesia, National Program for the Prevention and Early Detection of Cervical and Breast Cancer, 2015). The screening program has been proven to be effectively implemented to reduce the incidence of cervical cancer in developed countries (Catrino, 2015). The coverage rate for PAP smear screening is still low in Indonesia, and this is due to the low public knowledge about early detection of cervical cancer (Arani, 2019 and Domingo, 2018). The low number of PAP smears coverage is the concern of researchers who are scientifically engaged in the field of Anatomical Pathology and Clinical Pathology.

The results of the health survey conducted by Faculty of Medicine and Health Sciences, University Warmadewa in Puhu Village, Payangan, Gianyar, Bali showed that married women awareness for cancer screening is still low and was equal to $12 \%$ (Widarsa, 2017). Puhu village is one of the assisted villages by Warmadewa University Faculty of Medicine and Health Sciences. The village has the potential number of female population of 2795 people with a number of health facilities that consist of one sub-district health center (Puskesmas), seven Integrated Service Post (Posyandu) and three midwife clinics.

The preliminary study was conducted using interviews, questionnaires, and direct observations of three midwives, five village cadres, and the village community. The researchers found that the low coverage of cervical cancer screening in this area was due to the lack of promotion of Puskesmas programs. This was because there were still cadres who did not know that routine PAP smear examinations could be done at the Puskesmas or Puskesmas Pembantu (Pustu/Community Health Sub-Center). Puskesmas had provided PAP smear services on every weekday or once a month at Pustu as well as free examinations on certain days, but screening participants were still low, which was less than 10 women. The findings of the visit to the Pustu showed that Pustu midwives had not independently served PAP smears at the facility; they were still assisted by medical personnel from the Payangan's sub-district health center. This was 43 www.jurnal.ugm.ac.id/jpkm because the number of participants was still low and the technique for performing PAP smears was right. The results of interviews with the community around the Pustu also showed their reluctance to have the examination because the distance from their house to the Puskesmas was too far while the community did not know that the Pustu, which was closer than the Puskesmas, also had provided this service once a month. Another reason was that they were afraid to have themselves checked, and they felt unprepared if the PAP smear results showed that they had a malignant cancer.

The role of cadres in participating to increase the coverage of screening had been carried out such as through motivating the community to take PAP smears, but the survey results showed that these cadres had encountered obstacles in convincing the community. The community did not want to take the screening even though PAP smear services were offered free of charge. The village cadres had little knowledge of this, and most of them had not been screened with PAP smears themselves. Therefore, these cadres had not been able to persuade, encourage, and motivate women in the village. From the results of the interview, it was also found that the cadres themselves still had a misunderstanding about PAP smears screening, and this had created a pessimistic attitude among the cadres.

For this reason, the researchers who have expertise in the field of Anatomical Pathology and Clinical Pathology at Warmadewa University Faculty of Medicine made an attempt to increase the public awareness in Puhu village, Gianyar, Bali, about the importance of early detection of cervical cancer which is designed in the form of the "Cervical Cancer Awareness Movement" (Gerakan Sadar Kanker Serviks/Gardavi). This movement aimed to reduce morbidity and mortality among adult women due to cervical cancer by increasing cervical cancer screening coverage rate. The effort to increase public participation in Puhu Village was done in cooperation with midwives from Community Health Sub-Centre of Puhu Village referred to as partner 1 and five Puhu village cadres referred to as partner 2 .

\section{METHOD}

\subsection{Increasing the participation of Pustu midwives}

To increase the role of the Community Health SubCenter in Puhu Payangan Village, Gianyar in disseminating information about the PAP smear screening activity program, researchers prepared brochures, each of which contained general knowledge of cervical cancer, the benefits of PAP smear screening, and the schedule of PAP smear examinations at the Pustu. From the distribution 
of these brochures, it was expected that the people of Puhu Payangan village would be informed about the program. This distribution was accompanied by a tiered activation of the information system for village midwives, cadres, and the community both verbally and in a group on social media to create a tiered coordination system. This method was expected to be effective in disseminating information about the schedule of the screening to the Puhu village community aiming to cover more than 10 people for the PAP smear screening in each activity.

Pustu midwives had not independently served PAP smears and still been assisted by medical personnel from Puskesmas Payangan. To increase the participation of Pustu midwives in increasing their services, so that these can become more accessible for the surrounding community and their independence, the researcher team trained these midwives how to preform PAP smears through mentoring and independent training. The assessment of the midwives' learning outcomes (their skill development) was done using a check list of PAP smear techniques, analyzing the quality of PAP smear slides the midwives took, grading their ability to carry out the screening independently.

\subsection{Increasing the participation of cadres}

Empowering Puhu Village PKK (Family Welfare Empowerment) cadres to mobilize active participation of women/mothers in Puhu Village was carried out by means of transferring knowledge about cervical cancer and PAP smear screening. This activity was expected to increase the cadres' knowledge about cervical cancer and the benefits of PAP smear screening. The evaluations of this program were carried out using a pretest and posttest. It was expected that after the knowledge transfer, the cadres would become more knowledgeable and have more understanding about both cervical cancer and PAP smear test. These achievements could be discovered through the participants' post test scores.

The cadres were also motivated to act as role models in their community in disseminating information about early detection of cervical cancer, and all of the cadres was also given opportunities have PAP smear screening. The numbered head together method was carried out by dividing the cadres into 2 groups. Each group was guided by one supervisor, and there were three to five prospective PAP smear participants who would be given motivation. Each cadre was given an opportunity to demonstrate the recruitment. The supervisor encouraged, appreciated, and provided inputs. The success of this program would be assessed through the increased ability of the cadres in motivating the prospective screening participants. The cadres were expected to be optimistic about recruiting, successful in inviting participants to come for screening, able to independently recruit participants. The independent recruitment of screening participants was assessed from videos and photos taken during the independent recruiting activities.

\section{RESULT AND DISCUSSION}

This community service was carried out in several stages by involving midwives, cadres, and villagers. The activity began with a briefing and knowledge transfer attended by the researchers and village cadres. This briefing aimed at transferring knowledge about cervical cancer and the benefits of early detection (Figure 1A). The results of the questionnaire before and after the briefing are presented in Table 1. The results of the evaluation showed that there was an increase in the knowledge of the cadres by $104 \%$ compared with their knowledge before the briefing. Increasing the cadres' knowledge was an effort to strengthen the role of these cadres in disseminating and conveying correct information to the public.

Table 1. The assessment of pre-test and post-test of cadres' knowledge questionnaire

\begin{tabular}{|c|c|c|c|c|}
\hline \multirow[t]{2}{*}{ No. } & \multirow[t]{2}{*}{ Cadres } & \multicolumn{2}{|c|}{ Score } & \multirow{2}{*}{$\begin{array}{c}\text { Improv } \\
\text { ement } \\
(\%)\end{array}$} \\
\hline & & Pretest & Posttest & \\
\hline 1 & Cadre 1 & 40 & 90 & 125 \\
\hline 2 & Cadre 2 & 35 & 85 & 142 \\
\hline 3 & Cadre 3 & 55 & 85 & 55 \\
\hline 4 & Cadre 4 & 45 & 90 & 100 \\
\hline 5 & Cadre 5 & 45 & 90 & 100 \\
\hline & $\begin{array}{l}\text { Mean } \\
\text { Score }\end{array}$ & 36 & 88 & 104 \\
\hline
\end{tabular}

The pessimistic attitude of the cadres to recruit participants was a concern for the researchers. These cadres also felt afraid to have PAP smear test. Most of the cadres ( 4 out of 5 people) had never done a PAP smear examination. The researcher motivated the cadres to have a PAP smear examination before they could recommend it to other women. It would have certainly been better if the sufficient knowledge of cadres had been supported by an optimistic attitude. This was because these cadres were the role models for their community. Cadres who already had experience doing a PAP smear screening would have more confidence in recruiting the women in their community. The cadres were also expected to be able to explain the false stereotype about this examination. 


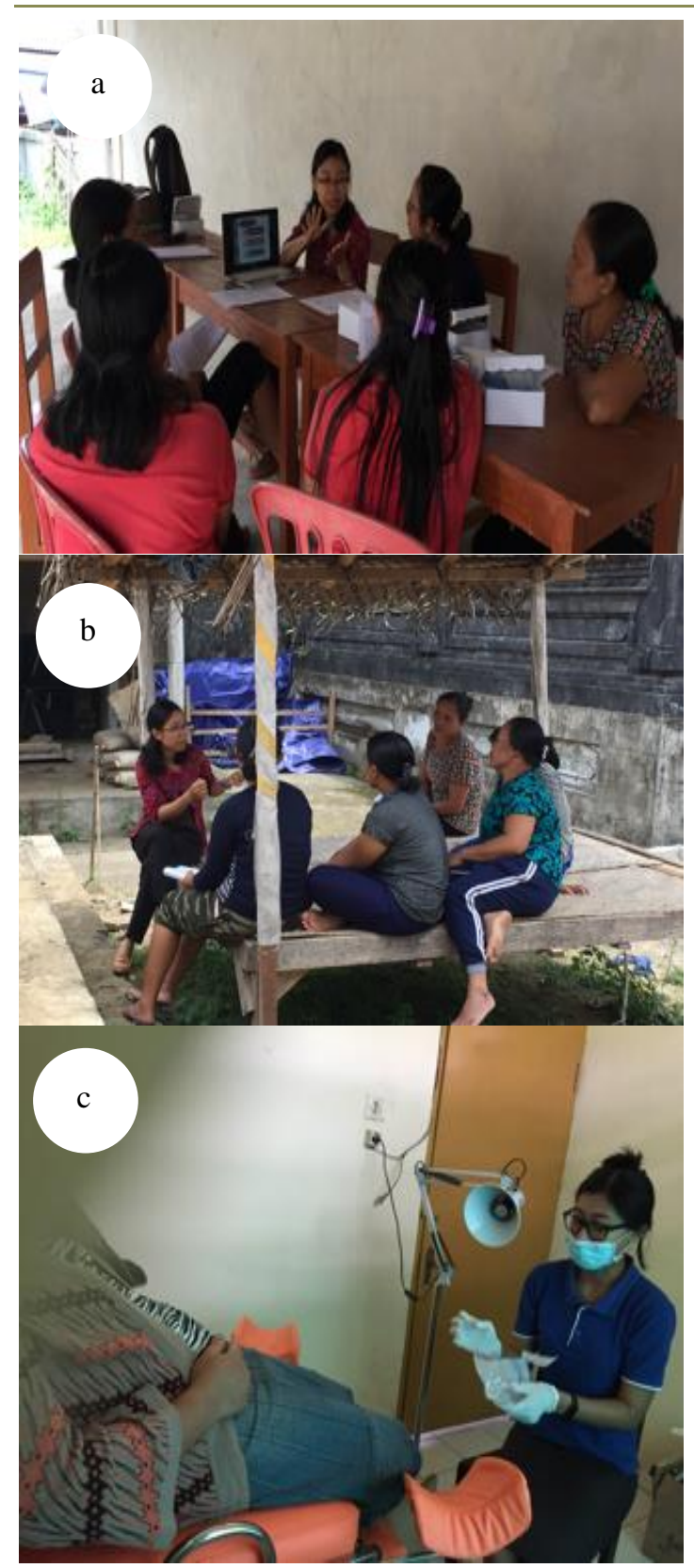

Figure 1. A providing material and motivating cadres, B. Guidance per group, C. Midwifery training Source: Lestari, D.P.O (2018)

The next stage was to build an optimistic attitude among cadres. Cadres with sufficient knowledge, having good self-confidence, and being polite would be able to invite and influence people in their community. The researchers trained how to utilize a good recruitment system and gave motivation to the cadres. Subsequently, the researchers conducted mentoring for the cadres through dividing them into 2 groups, each of which consisted of two to three cadres and was accompanied by a supervisor/mentor, who was one of the researchers (Figure 1B). Each group was faced with a small community group consisting of five to six mothers/women. Each cadre was given an opportunity to perform the recruitment. The indicators assessed from each cadre are listed in Table 2.
Table 2. Results of cadres observation in recruiting community members

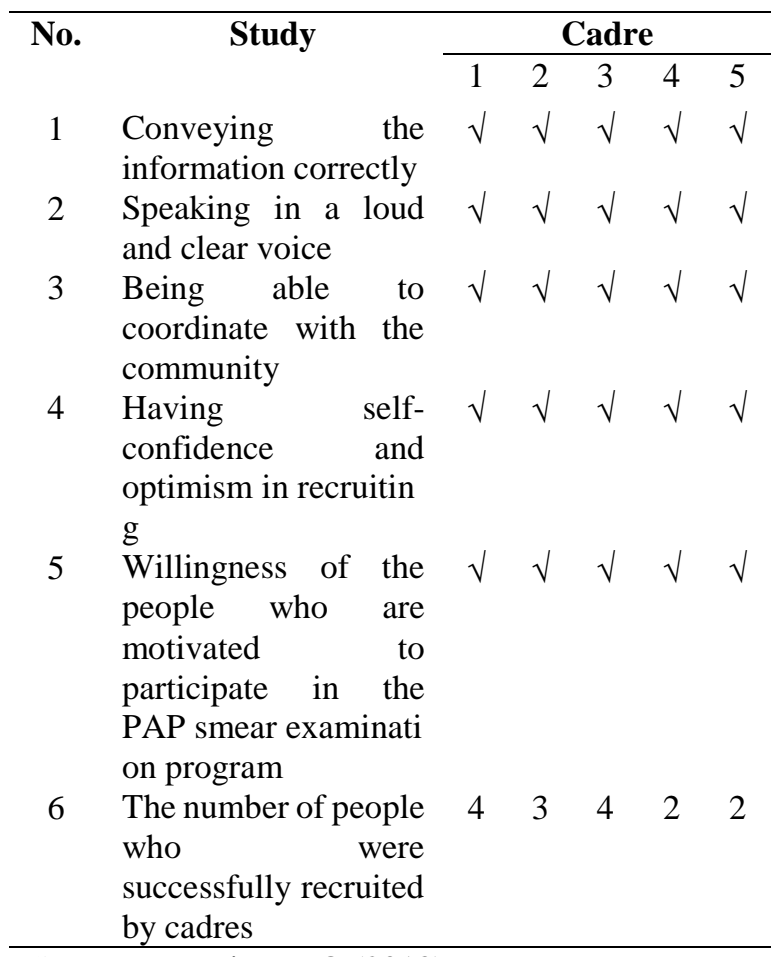

Source: Lestari, D.P.O (2018)

This process succeeded in motivating four out of five cadres, who had previously felt scared and had never had a PAP smear test, to be willing to have themselves examined. Having experienced the screening made the cadres more optimistic in recruiting participants. The cadres succeeded in motivating and recruiting 15 mothers who were then scheduled to take part in the first phase of PAP smear screening activity on the day adjusted to the regular activities of the Pustu. On that occasion, an evaluation stage was carried out on the cadres' impressions after participating in the PAP smear screening. They said that what they had thought about PAP smear examinations before was not true. They also expressed their gratitude for being given the opportunity to have themselves checked, and they would confidently independently recruit for the second stage of the PAP smear screening.

The cadres were given the opportunity to carry out the recruitment independently without assistance in the next stage with the help of a coordinated system that had been formed in collaboration with village officials. The cadres disseminated information by distributing brochures, conducting recruitment, and providing information about PAP smear screening to community members who gathered at the village's pura before a religious ceremony began. Some cadres carried out the recruitment during village meetings; other cadres chose to approach mothers/women who had never been screened at their homes, and they sent the videos or photos of their recruitment. The number of participants who were recruited by the five cadres was 28 people. The second PAP smear activity was 
carried out at Puhu Village's Pustu at the time agreed by the Pustu, village officials, the cadres, and the community. This activity ran smoothly, and many participants came, showing the increase in the coverage of the PAP smear test. People who had been independently recruited by the cadres stated their willingness during recruitment. This was the result of the good communication and cooperation among the village community, village officials, the head of Puhu Village, the cadres, the village midwives, and Puhu Village Health Center. This cooperation was promoted through communication in both a WhatsApp group and social interactions.

The results of the interviews with the cadres at the end of the event showed that the change in the attitude of the cadres occurred. They became more confident and optimistic resulted in succeed in recruiting participants. In addition, the evaluation results of the videos sent by the cadres and their success in independently recruiting the screening participants were indicators of the cadres' success in increasing the coverage of PAP smear tests at the Pustu. The average number of people's visits to the Pustu to have PAP smears before this community service program was conducted was less than 10 or reached a maximum of 10 people. The number of visits in the first
PAP smear screening was 20 people. This number showed an increase in the coverage of PAP smears by $50 \%$, and the number increased to 28 people in the second activity. In total this number increased by $180 \%$.

Midwives, who are at the forefront of primary health care provision in the village, play an important role in reducing the incidence of cervical cancer by trying to increase the coverage rate of the PAP smear examination. The role of the village midwives was strengthened through helping to activate independent PAP smear screening by the midwives at the Puhu Village Community Health Sub-Center. In order to produce good quality slides that are ready to be referred, training on PAP smear sampling and the process of coloring the slides using the correct technique is necessary (Table 3). With the method of mentoring technique (Figure 1C), the midwives had become able to work in accordance with the procedural checklist. However, the fixation technique using alcohol 95\% was still an open system. It was suggested to use a closed system for the fixation method to prevent the fixation liquid from evaporating easily. This input received very positive responses and the closed system was applied during the second screening activity, which was carried out independently.

Table 3. Evaluation results of the skills in taking samples by the pustu midwives in Puhu Village

\begin{tabular}{|c|c|c|c|}
\hline No & Type of Activity & $\begin{array}{c}\text { PAPS } \\
\text { Stage I }\end{array}$ & $\begin{array}{c}\text { PAPS } \\
\text { Stage II }\end{array}$ \\
\hline 1 & Filling in the PAP smear examination form according to the standards & $\sqrt{ }$ & $\sqrt{ }$ \\
\hline 2 & $\begin{array}{l}\text { Preparing the PAP smear equipment: } \\
\text { slide, sterile speculum, flashlight and GIN table, sitobrush, and chlorine }\end{array}$ & $\sqrt{ }$ & $\sqrt{ }$ \\
\hline 3 & Slide Fixation Method with Alcohol 95\%: closed container method & - & $\sqrt{ }$ \\
\hline 4 & $\begin{array}{l}\text { Asking the patient to lie down in the lithotomy position, inserting the } \\
\text { speculum, observing the condition of the cervix }\end{array}$ & $\sqrt{ }$ & $\sqrt{ }$ \\
\hline 5 & $\begin{array}{l}\text { The technique to take samples for PAP smear } \\
\text { Putting the sitobrush into the cervical canal until all the brush is in }\end{array}$ & Good & $\underset{\sqrt{ }}{\text { Good }}$ \\
\hline & $\begin{array}{l}\text { Rotating the sitobrush } 360^{\circ} \\
\text { Making a smear on the slide using the sitobrush twisting technique }\end{array}$ & - & $\begin{array}{l}\sqrt{ } \\
\sqrt{ }\end{array}$ \\
\hline \multirow[t]{3}{*}{6} & $\begin{array}{l}\text { PAP smear Slide Evaluation } \\
\text { Slide Quality }\end{array}$ & $\begin{array}{l}20 \text { slides } \\
\text { Poor: } 8 \text { slides } \\
\text { Good: } 12 \text { slides }\end{array}$ & $\begin{array}{l}28 \text { slides } \\
\text { Good: } 28 \text { slides }\end{array}$ \\
\hline & Adequate number of epithelial cells & $\begin{array}{l}\text { Poor: } 8 \text { slides } \\
\text { Good: } 12 \text { slides }\end{array}$ & Good: 28 slides \\
\hline & Endocervical component contents and transformation zone components & $\begin{array}{l}\text { Negative: } 6 \text { slides } \\
\text { Positive: } 14 \\
\text { slides }\end{array}$ & $\begin{array}{l}\text { Negative: } 1 \\
\text { slide } \\
\text { Positive: } 27 \\
\text { slides }\end{array}$ \\
\hline
\end{tabular}

Source: Lestari, D.P.O (2018) 
Assessment of the referred slides' quality was carried out based on several criteria, which were the quality of the smear, the adequacy of the number of cells, and the presence of endocervical cell components and the transformation zone. From the results of the slide review, it was found that most of the slides were of good quality; only a few slides were of poor quality.

At the end of this community service activity, an evaluation stage was carried out and an appreciation was given to the midwives and cadres for their involvement symbolized by embedding the Gardavi PIN (Figure 2). Apart from being a souvenir, this pin was also expected to inspire the village cadres and midwives to continue to be active in fighting cervical cancer by continuously increasing the number of PAP smear coverage.
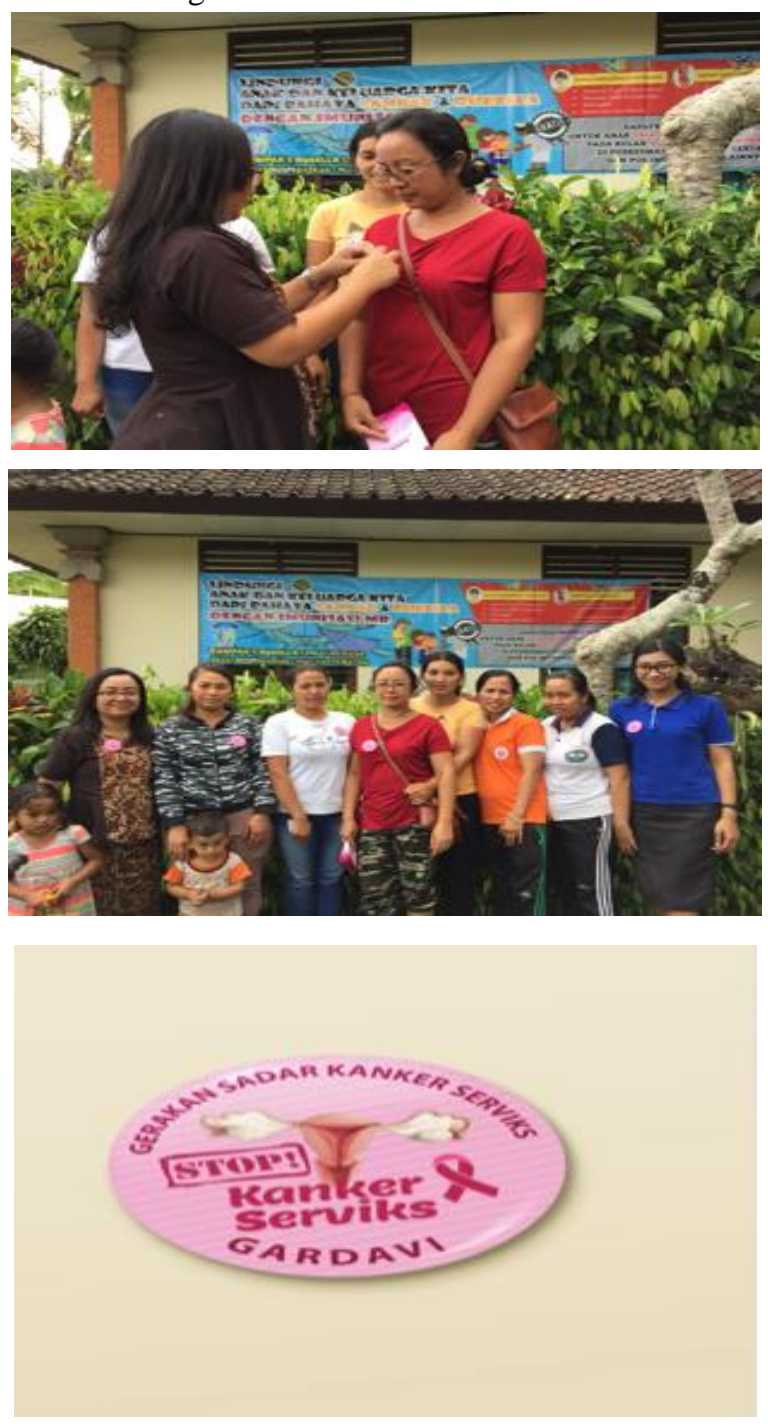

Figure 2. Embedding GARDAVI pin to the cadres and midwives of Puhu Village, Payangan, Gianyar

\section{CONCLUSION}

The program of empowering the cadres and midwives in Puhu Village to increase their awareness of cervical cancer was successful in increasing the participation of the village midwives in independently performing PAP smears, improving the quality of PAP smear services, increasing the knowledge of the village cadres, and motivating the village cadres to have PAP smear examination and recruitment in the GARDAVI program. The researchers hope that this activity will promotes the same program to increase the cervical cancer screening coverage in all areas or villages throughout Bali.

\section{REFERENCE}

Akinlotan, M., \& Bolin, J. (2017). Cervical cancer screening barriers and risk factor knowledge among uninsured women. Journal of Communitiy Health, 42(4), 770-778. DOI: https://doi.org/10.1007/s10900-017-0316-9

Anfinan, N., \& Sait, K. (2020). Indicators of survival and prognostic factors in treated for cervical cancer at a tertiary care center in Saudi Arabia. Annals Of Saudi Medicine.

Arani, M. (2019). Keikutsertaan Wanita Pasangan Usia Subur (PUS) Dalam Melakukan Deteksi Dini Kanker Serviks Dengan Metode IVA (Inspeksi Visual Asam Asetat) Di Wilayah Kerja Puskesmas Simpang. Journal of Midwivery Science, 3(1), 22-24.

Catarino, R., Petignat, P., Dongui, G., \& Vassilakos, P. (2015). Cervical Cancer Screening in Developing Countries at a Crossroad: Emerging Technologies and Policy Choices. World journal of clinical oncology, 6(6), 281290. DOI: https://doi.org/10.5306/wjco.v6.i6.28 1

Domingo, E. J., Noviani, R., Noor, M. R., Ngelangel, C. A., Limpaphayom, K. K., Thuan, T. V., Louie, K. S., \& Quinn, M. A. (2008). Epidemiology and prevention of cervical cancer in Indonesia, Malaysia, the Philippines, Thailand and Vietnam. Vaccine, 26 Suppl 12, M71-M79. DOI:

https://doi.org/10.1016/j.vaccine.2008.05.039

Indonesia, D. J. (2011). Kanker di Bali Tahun 2011. In Kanker di Indonesia Tahun 2011. Jakarta.

Medik, D. J. (2011). Kanker di Bali Tahun 2011. Jakarta.

RI, K. K. (2015, April). Program Nasional Gerakan Pencegahan Dan deteksi Dini Kanker Leher Rahim Dan Kanker Payudara. Jakarta, DKI Jakarta, Indonesia.

Stoler, M. (2014). Squamous Cell Tumours and Precursors. In J. R. Kurman, M. L. Carcangiu, C. S. Herrington, R. H. Young, \& Lyon, WHO Classification of Tumours of Female Reproductive Organs (pp. 170-182). Lyon: WHO.

Widarsa, T. (2017). Survei Kesehatan Desa Payangan Gianyar Sebagai Desa Binaan Fakultas Kedokteran Universitas Warmadewa. Denpasar. 